\title{
Socioeconomic factors and risk for hospitalisation due to asthma in children in the municipalities of Mato Grosso State, Brazil
}

\author{
Fatores socioeconômicos e risco para a hospitalização por asma \\ em crianças em municípios de Mato Grosso, Brasil
}

Elaine Cardoso de Oliveira Souza ${ }^{1}$

Emerson Soares dos Santos ${ }^{2}$

Antonia Maria Rosa ${ }^{3}$

Clóvis Botelho ${ }^{4}$

${ }^{1}$ Instituto de Saúde Coletiva, Faculdade de Ciências da Saúde, Universidade Federal de Mato Grosso (UFMT). Av. Fernando Corrêa da Costa 2367, Boa Esperança. 78060-900 Cuiabá MT Brasil. elaineoliveira_fisio@ hotmail.com

${ }^{2}$ Departamento de Geografia, Instituto de Geografia, História e Documentação, UFMT. ${ }^{3}$ Faculdade de Ciências da Saúde, Universidade do Estado de Mato Grosso. Cuiabá MT Brasil.

${ }^{4}$ Faculdade de Medicina, UFMT. Cuiabá MT Brasil.
Abstract This ecological study used data accumulated between 2001 and 2012 hospital admissions of children under five years of age with asthma in 141 municipalities in the Mato Grosso. Hospital data were extracted from the SIH/SUS system, and hospitalisation rates were estimated using the Bayesian inference method. SaTScan software was used for the calculation of the relative risk $(R R)$. Differences in socioeconomic characteristics among municipalities with high and low hospitalization rates were evaluated by nonparametric Wilcoxon-Mann-Whitney test. This test indicates that municipalities with better socioeconomic characteristics have lower hospitalization rates. The analysis of the linear models in the two study periods indicated that the decreasing trend in the number of admissions was 3-fold higher in the 2005-2012 period compared with the 2001-2004 period. In addition, a decrease of 76\% in the hospitalisation incidence rate was observed during the 12-year study period; this decrease was more evident from 2005 onward. The municipalities identified as having increased risk of hospitalisation of children with asthma were located in areas subjected to intense burning practices and with low municipal development indices.

Key words Asthma, Relative risk, Spatial analyst, Child
Resumo Trata-se de um estudo ecológico com dados de hospitalizações de crianças menores de cinco anos de idade com asma, entre 2001 a 2012, nos 141 municípios do estado de Mato Grosso, com o objetivo de analisar a distribuição e o risco de hospitalização por esse problema em crianças no estado de Mato Grosso. Os dados hospitalares foram extraídos do SIH/SUS e as taxas de internação foram estimadas por meio do método de inferência bayesiana. Para realização do cálculo do risco relativo $(R R)$ utilizou-se a técnica de varredura espacial, com o software SatScan. Diferenças de características socioeconômicas entre municípios com altas e com baixas taxas de hospitalização foram avaliadas pelo teste não paramétrico de Wilcoxon-Mann-Whitney. Avaliou-se que municipios com características socioeconômicas melhores têm menores taxas de hospitalização. Além disso, foi verificada uma redução de $76 \%$ ao longo de doze anos, mais evidenciada a partir de 2005. Os municipios identificados com maior risco de hospitalização de crianças por asma localizam-se em áreas com intensa atividade de queimadas e baixo indice de desenvolvimento municipal.

Palavras-chave Asma, Risco relativo, Análise espacial, Criança 


\section{Introduction}

Asthma is a chronic and multifactorial disease resulting from a complex interaction between genetic, socioeconomic, and environmental factors ${ }^{1}$.

The need for hospitalization suggests lack of disease control because of difficulties in treatment, and increased exposure to risk factors that trigger complications. In addition to causing considerable suffering and harm for the child and his/her family, the hospitalisation is costly and can often be prevented via environmental control measures, education of patients and their families, and adequate drug therapy ${ }^{1}$.

The main risk factors for hospitalisation are acute respiratory infections, being under five years of age, asthma severity, climatic factors, and exposure to environmental pollution ${ }^{2-6}$. All these characteristics are geographically heterogeneous, with existence of areas that add favorable conditions for infection and subsequent worsening of asthma in children.

In this context, understanding the spatial distribution of hospitalisation of children with asthma in Mato Grosso may be important for the implementation of public policies and health surveillance strategies by providing information that can support the planning of actions aimed at expanding the control of asthma in priority geographic areas. The identification and characterization of these areas can be performed by scanning spatiotemporal Scan, that can be executed in SaTScan software ${ }^{7}$, which calculates the relative risk of occurrence of an event within a study area. Epidemiologists worldwide use this software to describe spatial clusters of infectious and chronic diseases, disease vectors, and risk factors ${ }^{8}$.

Considering that the rate of hospitalisation for asthma is an indicator of disease severity and of the success of disease control, this study aimed to assess the spatial distribution and the risk of hospitalisation of children with asthma in Mato Grosso according to the place of residence.

\section{Methods}

This descriptive, epidemiological, and ecological study was conducted to assess the relative risk of hospitalisation of children with asthma in different municipalities. The study was conducted in the state of Mato Grosso, located in the midwest region of Brazil, with a population of 3,182,113 inhabitants 9 , and the study units consisted of the 141 municipalities in the state.

The study was conducted between 2001 and 2012, and the cases investigated were the records of hospitalisation after the diagnosis of asthma in children living in these municipalities aged 4 years, 11 months, and 29 days until the date of admission. The objective of this paper is not to identify homogenous areas or the formation of high-risk groups of municipalities, instead, we aimed at identifying local-level associations between social characteristics and asthma-related hospitalizations scenarios by choosing municipalities as units of areas for our analysis.

The demographic data used in this study were obtained from the Brazilian Institute of Geography and Statistics (Instituto Brasileiro de Geografia e Estatística-IBGE), whereas the hospitalisation data were obtained from the Hospital Information System of the Unified Health System (Sistema de Informações Hospitalares do Sistema Único de Saúde-SIH/SUS). The Authorisations of Hospital Admissions (Autorizações de Internações Hospitalares-AIH) that covered short stay, paid, and non-elective hospitalisations were used and clustered by municipality in the state of Mato Grosso according to the place of residence. The AIH classified as asthma-related morbidities (ICD-10: J45.0, J45.1, J45.8, and J45.9) and diagnosed in children under five years of age in the period between 2001 and 2012 were included.

\section{Risk relative analysis and spatiotemporal analysis}

For data analysis and calculation of the relative risk (RR) with a significance level of $99 \%$, SaTScan software was used, available at www. satscan.org.

In this software, the area is associated with a single point in a polygon, designated the centroid. The RR is calculated as the observed number of cases divided by the expected number of cases. RR $>1$ indicates that the observed number of cases is greater than the expected value. The Relative Risk is a relative associations measure is based on the force of association that has been commonly used in epidemiological studies ${ }^{10}$. Statistical significance was defined in terms of a $p$ value $(0.05)^{11}$.

To calculate the RR, data on the population profile, number of cases (adjusted for gender), and plane coordinates (Lambert Conformal Conic Projection: Central Meridian: W56.0; Latitude of Origin: S13.0, Metric units) of the centroid of 
each municipality were used. The Poisson probability model was used, which involves the analysis of count data, i.e., takes into account the number of individuals with a certain disease ${ }^{12}$. Because of the high amount of records during the years of 2003 and 2004, in addition to the new type of data behavior started in 2005, in contrast to the previous years, the historical series have been divided in two periods. The first period correspond to the years of 2001 to 2004 and the second period refers to 2005 to 2012 . The data regarding both periods were analyzed separately.

The hospitalization rates for each city were estimated through the Bayesian inference method by using the Empirical Local Bayesian Model, which estimates one rate for each city taking into account the values of neighbor municipalities, conducted with TerraView 4.1.0 software ${ }^{13}$. The use of this technique decreases the reliability on the rate observed in the case of reduced populations ${ }^{14}$, however, its use diminishes the random fluctuation, caused majorly by great differences among the populations in the municipalities analyzed enabling to compare the municipalities, even with distinguished populations. In this paper, the objective of using the Bayesian inference is to map the hospitalization rates for exploratory analysis. The local empirical Bayes smoother has been detailed by Souza et al. ${ }^{15}$ as follows:

$\widehat{\theta}_{i}=w_{i} t_{i}+\left(1-w_{i}\right) \mu_{i}$

Where:

$\widehat{\theta}_{i}$ : estimated rate

$t_{i}$ : actual rate in each municipality ities

$\mu_{i}$ : average rate in neighbouring municipal-

$w_{i}$ : weighting factor

The average $\mu_{i}$ is estimated by $\widehat{\mu}=\frac{\Sigma y_{i}}{\Sigma n_{i}}$,

where $y_{i}$ is the number of cases in each municipality and $n_{i}$ is the population. The weighting factor $w_{i}$ is the rate variance between municipalities divided by the sum of this variance plus a fraction of the average

$$
\mu_{i} / n_{i}: w_{i}=\frac{\theta_{i}^{2}}{\theta_{i}^{2}+\frac{\mu_{i}}{n_{i}}} .
$$

Because of the large number of medical records obtained between 2003 and 2004 and because the data assumed a new trend starting in 2005 in relation to the years that preceded it, the time series was divided into two periods. The first period corresponds to the years 2001-2004, and the second period included the years 2005-2012.
Terraview 4.1.0 software s $^{13}$ was used to prepare maps of the spatial distribution of hospitalisation rates and RR, which analysed the digital grid of municipal boundaries provided by IBGE for the year $2012^{9}$.

\section{Analysis of the socioeconomic characteristics of municipalities}

For analysis of the socioeconomic characteristics of each municipality, the FIRJAN Index of Municipal Development (Índice FIRJAN de Desenvolvimento Municipal-IFDM) was used. This index is a composite indicator that assesses the level of regional socioeconomic development using a simple average of the results obtained in each of the three main areas of human development: employment and income, education, and health. The IFDM was created by the Federation of Industries of Rio de Janeiro and is published annually; this index is analysed at the municipal level and has a national coverage. The IFDM index varies between 0 and 1 such that the closer to 1 the value is, the better the development index ${ }^{16}$.

The hypothesis that the IFDM and its components present different values according to the group of municipalities with high or low asthma-related hospitalization rates for children (binary variable: 1-below the mean annual rate in Mato Grosso and 2-above the mean annual rate in Mato Grosso) was assessed using Mann-Whitney-Wilcoxon nonparametric test, more appropriate in the absence of regular data distribution ${ }^{17}$. We decided on the comparison of the means ${ }^{18}$ and the IFDM since, in this case, this measure of central tendency is more representative than the mean. The statistical analysis was carried out with SPSS software (v. 10, SPSS Inc. Chicago, IL) for significance levels of $(\alpha=) 0.05$.

\section{Results}

Between 2001 and 2012, hospitalisations due to respiratory causes accounted for $17 \%$ of the total records in the state of Mato Grosso. Among children under five years of age, hospitalisations due to respiratory causes represented $68 \%$ of all admissions; asthma was responsible for $13 \%$ of the admissions due to respiratory causes.

The SIH/SUS database contained 17,975 records of hospitalisations for asthma in children under five years of age living in 141 municipalities of Mato Grosso in the study period. Of these records, 59\% involved male children, and 41\% in- 
volved female children. Children under one year accounted for $23 \%$ of all hospital admissions, and children aged 1-4 years accounted for $76 \%$.

\section{Risk of child hospitalisation for asthma in the municipalities of Mato Grosso}

Figure 1 highlights the municipalities with high Relative Risks. By deciding on a scanning analysis purely spatial, although in two periods, it was not possible to verify the spatial patterns of municipalities with similar Relative Risks. In the first period, $51 \%(\mathrm{~N}=71)$ of the municipalities exhibited RRs $<1$. The municipalities with RRs between 1 and 2 accounted for $25.9 \%(\mathrm{~N}=36)$, and those with RRs between 2 and 5 accounted for $20.1 \%$. Those with RRs between 5 and 10 corresponded to $23 \%(\mathrm{~N}=32)$; of these, the municipalities of Porto Estrela $(\mathrm{RR}=9.77)$, Araguaiana $(\mathrm{RR}=8.42)$, and Barra do Bugres $(\mathrm{RR}=5.98)$ showed the highest RRs. Between the first and the second period, Araguaiana and Porto Estrela reduced the risk while Barra do Bugres remained stable.

In the 2005-2012 period, 75 municipalities (53.1\%) exhibited RRs $<1$, i.e., four municipalities less than in the 2001-2004 period. In addition, 35 municipalities (24.8\%) exhibited an RR between 1 and 2. The number of municipalities with RRs between 1 and 2 remained stable and corresponded to $24.9 \%$ in the first period and
$24.8 \%$ in the second period. The number of municipalities with RRs between 2 and 5 decreased from $28(20.1 \%)$ to 24 (17\%) from the first to the second period.

The number of municipalities with RRs $>5$ increased from four in the 2001-2004 period to seven in the 2005-2012 period, but those with RRs $>7$ decreased from two to one. In the 20052012 period, the municipalities with the highest RRs were Rio Branco $(\mathrm{RR}=7.59)$ and Araguaia$n a(R R=6.62)$.

\section{Hospitalisation rate of children with asthma in Mato Grosso}

Figure 2 (maps and plot) shows decreases in the hospitalisation rates in most municipalities in Mato Grosso. In 2001, the rate was $<5$ per 1,000 children in $28.1 \%$ of the municipalities. In 2012, the same rate was observed in $85.8 \%$ of the municipalities and reached $<1$ per 1,000 children in most of them.

After 2005, decreases in the central region of the number of municipalities with high rates. In this period, the municipalities of the north-northeast region and south-southeast of the state have increased in their rates, making the areas with the highest rates. Apiacás and Pocone, respectively, the north and south-ends remain throughout the period with moderate to high rates, for example.

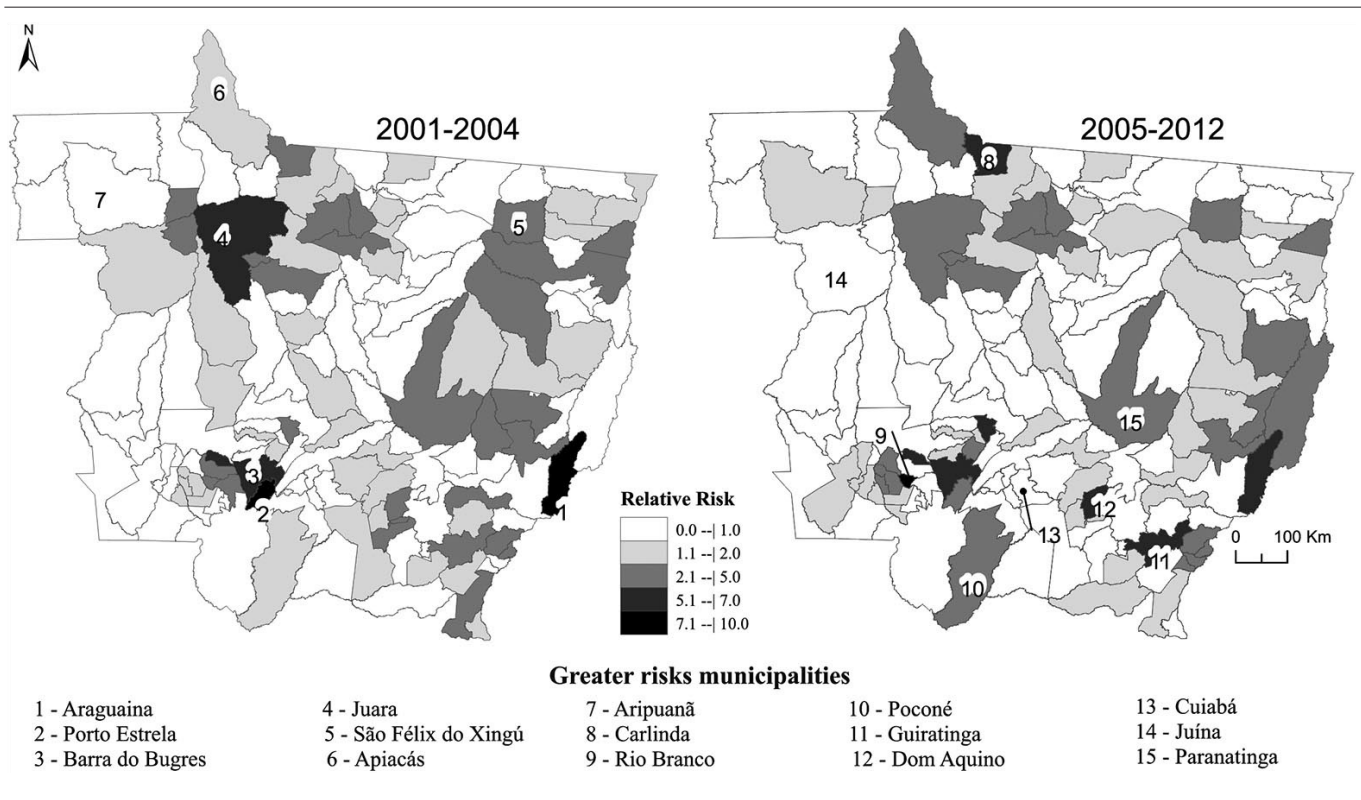

Figure 1. Relative risk of each municipality in the state of Mato Grosso, Brazil, 2001-2012. 


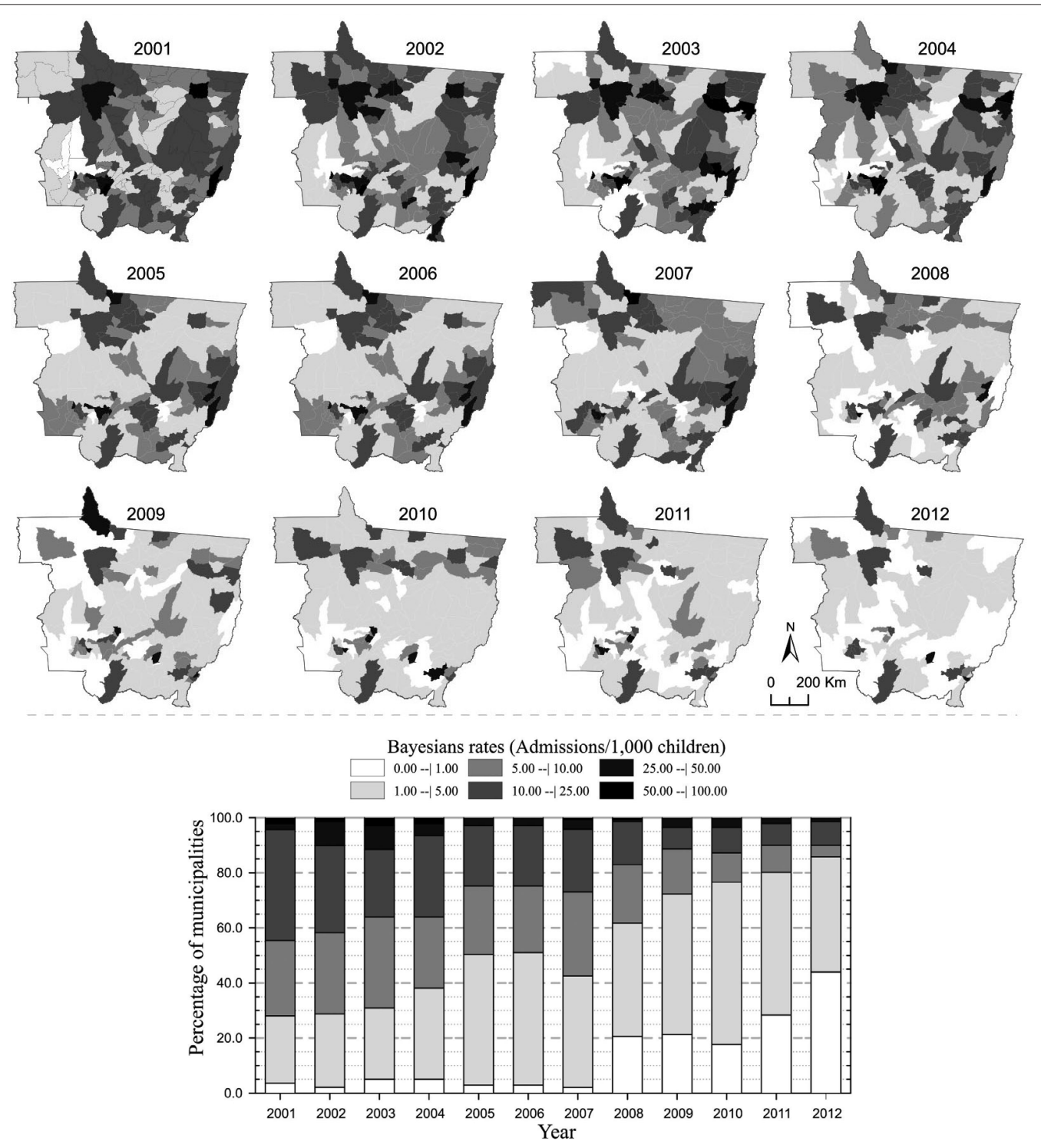

Figura 2. Children hospitalization rates for asthma according to place of residence in Mato Grosso, from 2001 to 2012.

In 2001, the hospitalisation incidence rate varied between 5 and 25 hospitalisations per 1,000 children in $65 \%$ of the municipalities. The highest incidence rate in the state during the study period was observed in 2003 , when it reached 8.4 hospitalisations per 1,000 children.

A rate decrease of $65 \%$ was observed in 2006 compared with the rate in 2001. However, the rates increased by $9.6 \%$ in 2007 compared with the rate in 2006. From 2008 onward, the rates decreased, and the average annual decrease was $12.6 \%$.

The gradual decrease in the hospitalisation rates was not observed in some municipalities of the state, including Barra do Bugres, Porto Estre- la, Araguaiana, Aripuanã, Apiacás, Alta Floresta, Poconé, and São José do Xingu. Although the hospitalisation rates decreased at some point in the period analysed, the incidence rates in these municipalities remained high.

\section{Temporal analysis}

Figure 3 presents the monthly hospital records obtained between 2001 and 2012. Note the increased numbers of hospitalisations in 2003 and 2004.

In addition, in the 2001-2004 period, the downward trend in the number of hospitalisations was small compared with the sharp decline 


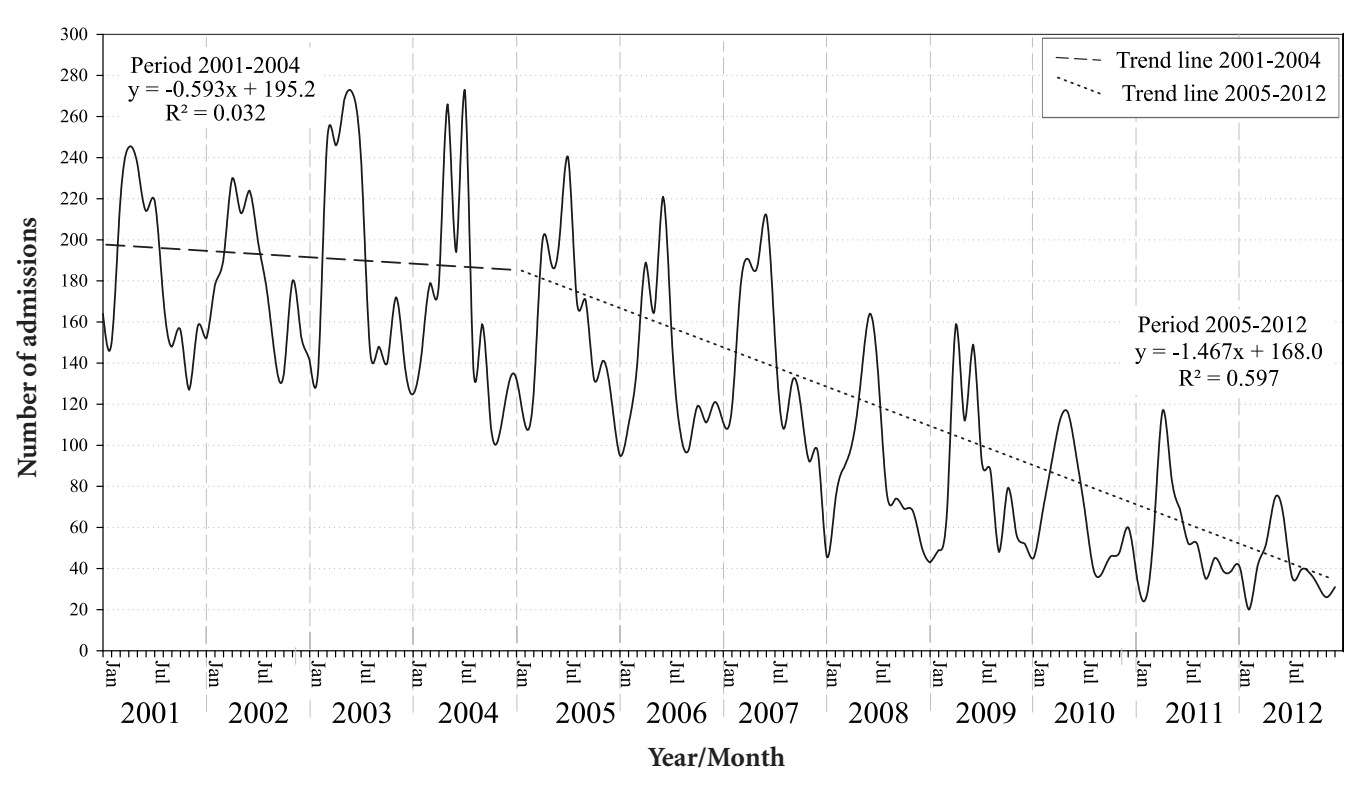

Figure 3. Trend of hospitalization of children for asthma in Mato Grosso, January 2001 and December 2012.

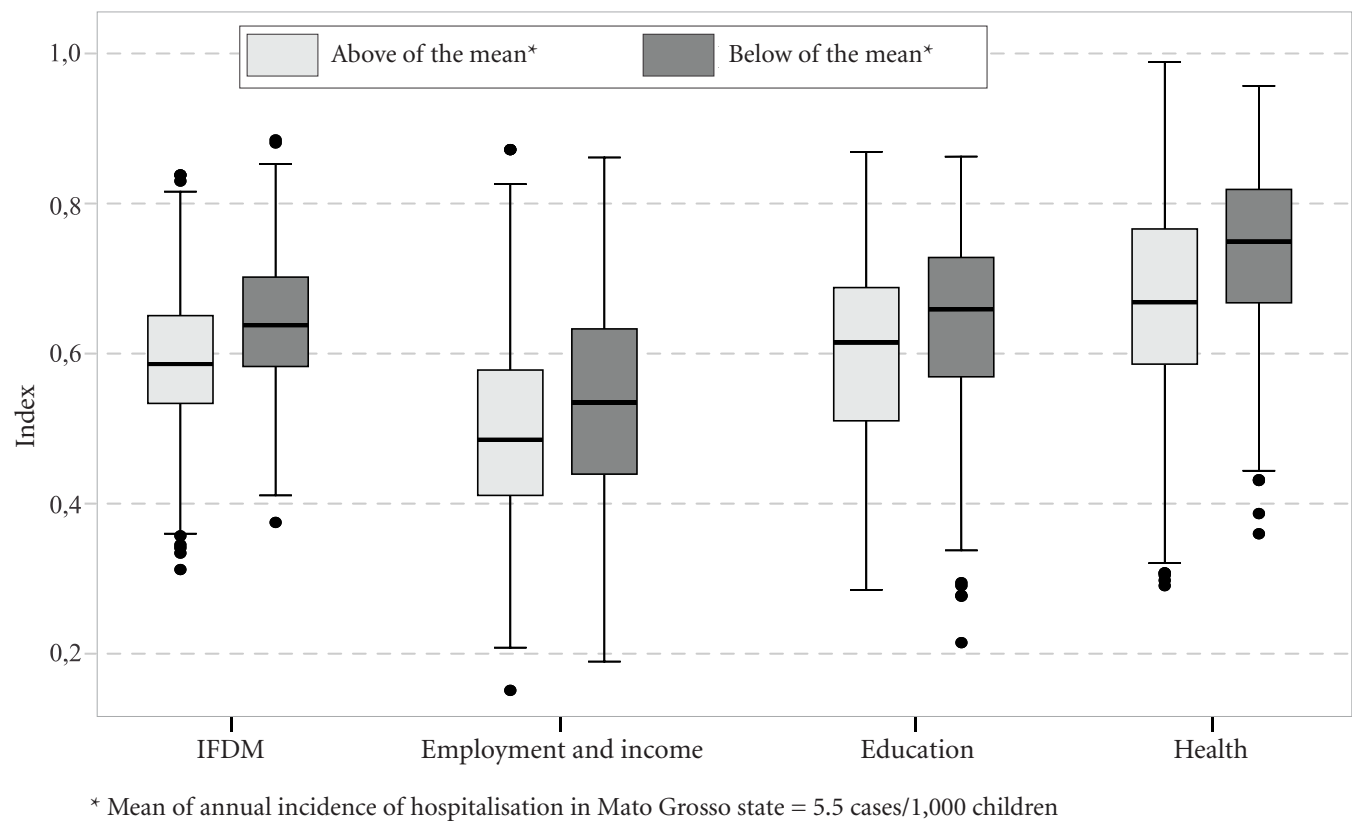

Figure 4. Box plot of the Index of socioeconomic characteristics, by groups of municipalities with values above and below the mean of annual incidence of hospitalization for asthma in children in the period 2001-2012 in Mato Grosso state.

observed from 2005 onward. The analysis of the linear models in the two study periods indicated that the decreasing trend in the number of admissions was 3-fold higher in the 2005-2012 pe- riod compared with the 2001-2004 period ( $\alpha=$ -1.467 in 2005-2012 vs. $\alpha=-0.593$ in 2001-2004), though the model of the first period was very weak $\left(r^{2}=0.032\right)$ due to the significant monthly 
data variability in the 4-year period. The effect of this monthly variability was mitigated in the second period because the time series consisted of an 8-year window, yielding increased model consistency $\left(r^{2}=0.597\right)$. Throughout the state, there was an average annual incidence of 5.53 hospitalisations per 1,000 children in the study period. This incidence decreased from 8.47 hospitalisations per 1,000 children in 2011 to 1.97 hospitalisations per 1,000 children in 2012, corresponding to a $76 \%$ decrease in the 12 -year period.

\section{Socioeconomic characteristics \\ of municipalities and rate of hospitalization for asthma}

The municipalities with incidence below the mean of annual incidence in state of Mato Grosso (5.53 / 1000 children) had IFDM and its indicators values larger than the municipalities with incidence above than the annual incidence state, statistically significant $(\mathrm{U}=[\mathrm{IFDM}=68953.5$; Employment $=82633,0$; Education $=77362.5$; Health $=70665.5], \mathrm{W}=[\mathrm{IFDM}=305,281.500$; Employment = 318,961.000; Education = $315,757.500$; Health $=309,060.500$ ], $\mathrm{p}=0.00$ [all variables]. The Figure 4 show the distribution of the IFDM and its indicator in the two groups of municipalities.

The risk values shown in Figure 4 evidence higher median in all the variables studied for municipalities groups with lower incidences, which indicates that the higher the Municipal Development, Employment and Income and better health conditions of a municipality, the lower your risk of hospitalization of children with asthma.

\section{Discussion}

The study of the spatial distribution of hospitalisation rates among children with asthma in Mato Grosso revealed that the municipalities with the highest rates between 2001 and 2012 were Alta Floresta, Araguaiana, Aripuanã, Barra do Bugres, Poconé, and São Felix do Xingu, with little variation in both periods analyzed and hospitalization rates remained high throughout the study period.

The Relative Risk (RR), measure employed in this study, consists of the ratio between the amount of occurrence of the disease in a certain area and the time and amount of people exposed in this same location and time. In raw form, this measure is highly influenced by rare occurrences or a reduced size of the population exposed. Nevertheless, in this study, even though these municipalities are small with an indicator that could present some random fluctuation and make the comparison with other municipalities weak, it is important to consider the use of Bayesian rates whose estimate of the municipal rate takes into account the values of neighbor municipalities, correcting this bias and making the interpretation of the municipal rates more reliable.

The association between high hospitalisation rates due to respiratory diseases and increased occurrence of burning practices has been widely reported in the literature ${ }^{19-24}$, as well as specifically in relation to straw burning of sugarcane $e^{25-28}$. It is known that exposure of the airways to pollutants emitted by burnings increases the permeability of the respiratory epithelium and thus decreases ciliary function and increases the release of pro-inflammatory mediators by epithelial cells ${ }^{29}$.

In addition, a possible relationship between unfavourable socioeconomic conditions of the general population and increased risk of hospitalisation of children for asthma should be considered in these municipalities. According to the last census conducted in 2010, these municipalities are considered small, and between $68 \%$ and $84 \%$ of their residents above 18 years of age are economically active, with incomes of up to 2 times the minimum wage. Another important factor is that the average educational level was below the national average in these municipalities, which corresponds to $54.9 \%$ of residents above 18 years of age with complete primary ${ }^{30}$.

The differences the index of socioeconomic characteristics between the municipalities with high and low hospitalization rates strengthen this argument by stating that municipalities with low levels of development have higher rates of hospitalization of children with asthma. Previous studies have highlighted the existence of inequalities in hospitalisations for asthma in different regions ${ }^{31,32}$, suggesting that many factors are involved in increased disease severity among the poorer population groups ${ }^{32}$.

Income is an important factor to consider when analysing the high cost of drug therapy to control severe asthma, and this drug therapy not yet available in drugstores during the study pe$\operatorname{riod}^{33}$. In addition, differences in the household environments, including increased humidity, dust, and number of people in the household, may explain the higher rates observed in socially disadvantaged areas $^{34}$. 
The greater social vulnerability of children living in cities with very low FIRJAN Index leads to a higher environmental susceptibility since their families often guarantee their source of sustenance by working in cane fields and burning sugar cane from the harvest process releasing environmental pollutants that are harmful to the human health - a possible contribution to increased hospitalization rates. Lopes ${ }^{28}$ identified positive correlation between primary hotspots of sugar cane burning and asthma hospitalizations, as well as negative correlation between Municipal Human Development Index (M-HDI) and hospitalizations, reinforcing the data found in this study considering that the M-HDI is similar to the FIRJAN.

Furthermore, it is necessary to consider that despite having achieved larger coverage, between 2004 and 2012, the Family Health Centers in cities such as Apiacás, Alta Floresta, Aripuanã, Porto Estrela, and Barra do Bugres, 100 percent of the population is reached only in Porto Estrela. In Barra do Bugres, for example, just over a half of the population have access to ESF $(64.4 \%)$, according to Datasus ${ }^{35}$. Even for the cities covered in the aforementioned years, it is important to consider the quality of services using indicators from results and processes, which may contribute to understand the studied phenomenon.

Asthma hospitalizations are part of the list of conditions to receive primary care - conditions properly diagnosed and treated in such level should not evolve to hospitalization ${ }^{36}$. Therefore, a part of asthma hospitalization risk for children is probably attributed to the primary care; however, it does not fit the assessment scope of this study.

The significant decrease in the hospitalisation rate of children with asthma in the state of Mato Grosso during the study period is notable, especially in the second period. The hospitalisation rate decreased from 8.4 hospitalisations per 1,000 children in 2001 to 1.99 hospitalisations per 1,000 children in 2012, which corresponded to a decrease of $76.5 \%$. It is possible that the decreased rates observed are due to the expansion of the Family Health team, which had higher population coverage starting in $2005^{33}$. The improved socioeconomic conditions of the families in these municipalities may have contributed to the decreased rate because the second period coincided with the beginning of the income transfer programs established by the Federal Government.

An analysis of the results indicated that the implementation of the spatial scan technique was successful for the identification of municipalities at risk of asthma hospitalisations. The choice not to analyse the possible existence of space-time clusters of municipalities during the study period can be considered a weakness of this study, given that neighbourhood characteristics could be addressed to explain the presence of risk areas. Nevertheless, the municipalities considered high priority for the control of asthma in children were identified and included Barra do Bugres, Porto Estrela, Araguaiana, Aripuanã, Apiacás, Alta Floresta, Poconé, and São José do Xingu.

Even though the overall IFDM of the municipalities is within categories from regular to moderate human development, by unbundling the components, the mean of employment and income reveals regular development while health indicates moderate to high. Both are considered social determinants of health, which makes it important to enlarge the investment in job generation in the municipalities of the Mato Grosso state in order to increase the overall IFDM.

\section{Conclusion}

Social indicators, such as the FIRJAN index and its components - Employment and Income, Health and Education - have different values according to the groups of municipalities with high or low hospitalization rates, with the municipalities with better socioeconomic characteristics showing lower asthma-related hospitalization rates in children.. The intention of this study was not to analyze factors associated with different hospitalization rates among the cities; however, descriptive studies of this nature enable the identification of aspects that require further details on the issue.

The calculation of Bayesian rates was important to mitigate the annual random data fluctuation, allowing a more reliable interpretation of municipal rates. Linear models showed an accelerated decrease in the rates in the second period compared with the first period.

In conclusion, the spatial distribution of hospitalization risk for children with asthma in Mato Grosso according to the city reveals a higher-risk concentration in cities with sugar cane plantations or surrounding areas. Coincidently or not, part of these cities have the lowest FIRJAM indices of the state, reinforcing the results pointing out that the worse the conditions of health, employment, and outcome in the city the higher the risk of asthma hospitalization. 


\section{Collaborations}

ECO Souza and ES Santos conceived the study design, performed statistical and spatial analysis and drafted the manuscript. AM Rosa and C Botelho conceived the study design and drafted the manuscript. All authors participated in the elaboration of final manuscript.

\section{Acknowledgments}

The authors would like to thank the Graduate Program in Public Health - UFMT and the CNPq.

\section{References}

1. GINA. Global Initiative for Asthma Management and Prevention [Internet]. 2014. [cited 2015 Feb 4]. Available from: http://www.ginasthma.org/

2. Kelly FJ, Fussell JC. Air pollution and airway disease. Clin Exp Allergy 2011; 41(8):1059-1071.

3. Brandão HV, Cruz CS, Guimarães A, Camargos PAM, Cruz AA. Fatores preditores de hospitalização por asma em crianças e adolescentes participantes de um programa de controle da asma. J Bras Pneumol 2010; 36(6):700-706.

4. Silva PRS, Rosa AM, Hacon SS, Ignotti E. Hospitalization of children for asthma in the Brazilian Amazon: trend and spatial distribution. J Pediatr 2009; 85(6):541-546.

5. Lasmar L, Goulart E, Sakurai E, Camargos P. Fatores de risco para hospitalização de crianças e adolescentes asmáticos. Rev Saude Publica. 2002 Aug; 36(4):409-419.

6. Hancox RJ. Relationship between socioeconomic status and asthma: a longitudinal cohort study. Thorax [Internet]. 2004 May 1 [cited 2015 Nov 4]; 59(5):376380. Available from: http://thorax.bmj.com/content /59/5/376

7. Kulldorff M. A spatial scan statistic. Commun Stat Theory Methods [Internet]. 1997 Jun 27 [cited $2015 \mathrm{Feb}$ 4]; 26(6):1481-1496. Available from: http://www.tandfonline.com/doi/abs/10.1080/03610929708831995\#. VNJkMmjF_4Y

8. Sherman RL, Henry KA, Tannenbaum SL, Feaster DJ, Kobetz E, Lee DJ. Applying spatial analysis tools in public health: an example using SaTScan to detect geographic targets for colorectal cancer screening interventions. Prev Chronic Dis 2014; 11:E41.

9. Instituto Brasileiro de Geografia e Estatística (IBGE). Rio de Janeiro: IBGE; 2013.

10. Kale P, Costa A, Luiz R. Medidas de associação e medidas de impacto. In: Medronho R, Bloch K, Luiz R, Werneck G, editors. Epidemiologia. 2a ed. Rio de Janeiro: Editora Atheneu; 2009. p. 181-190.

11. Jones SG, Kulldorff M. Influence of spatial resolution on space-time disease cluster detection. PLoS One 2012; 7(10):e48036.

12. McCullagh P, Nelder JA. Generalized Linear Models. $2^{\text {nd }}$ ed. London, New York: Chapman \& Hall; 1989.

13. Instituto Nacional de Pesquisas Espaciais (INPE). TerraView. São José dos Campos: INPE; 2012.

14. Brasil M da S. Introdução à Estatística Espacial para Saúde Pública. In: Santos S, Souza WV, editors. Capacitação e atualização em geoprocessamento em saúde. Brasília: Fiocruz; 2007. [Vol. 3]

15. Souza W, Carvalho M, Cruz O, Ragoni V. Análise Espacial de Dados de Áreas. In: Brasil. Ministério da Saúde (MS). Introdução à Estatística Espacial para a Saúde Pública. Brasília: MS; 2007. [Série Capacitação e Atualização em Geoprocessamento em Saúde].

16. Federação das Indústrias do Estado do Rio de Janeiro (FIRJAN). Índice FIRJAN de Desenvolvimento Municipal (IFDM): Consulta. Rio de Janeiro: FIRJAN; 2013.

17. Hettmansperger TP, McKean JW. Robust Nonparametric Statistical Methods. Boca Raton: Taylor \& Francis Group; 2011.

18. Wilcoxon F. Individual Comparisons by Ranking Methods. Biometrics Bull 1945; 1(6):80-83. 
19. Ignotti E, Valente JG, Longo KM, Freitas SR, Hacon SS, Artaxo Netto P. Impact on human health of particulate matter emitted from burnings in the Brazilian Amazon region. Rev Saude Publica 2010; 44(1):121-130.

20. Mascarenhas MDM, Vieira LC, Lanzieri TM, Leal APPR, Duarte AF, Hatch DL. Poluição atmosférica devida à queima de biomassa florestal e atendimentos de emergência por doença respiratória em Rio Branco, Brasil - Setembro, 2005. J Bras Pneumol 2008; 34(1):4246.

21. Künzli N, Avol E, Wu J, Gauderman WJ, Rappaport E, Millstein J, Bennion J, McConnell R, Gilliland FD, Berhane K, Lurmann F, Winer A, Peters JM. Health effects of the 2003 Southern California wildfires on children. Am J Respir Crit Care Med 2006; 174(11):12211228.

22. Lopes FS, Ribeiro H. Mapeamento de internações hospitalares por problemas respiratórios e possíveis associações à exposição humana aos produtos da queima da palha de cana-de-açúcar no estado de São Paulo. Rev Bras Epidemiol 2006; 9(2):215-225.

23. Mott JA, Mannino DM, Alverson CJ, Kiyu A, Hashim J, Lee T, Falter K, Redd SC. Cardiorespiratory hospitalizations associated with smoke exposure during the 1997, Southeast Asian forest fires. Int $J$ Hyg Environ Health 2005; 208(1-2):75-85.

24. Emmanuel SC. Impact to lung health of haze from forest fires: The Singapore experience. Respirology 2000; 5(2):175-182.

25. Cançado JED. A poluição atmosférica e sua relação com a saúde humana na região canavieira de Piracicaba - SP. São Paulo: Universidade de São Paulo; 2003;

26. Arbex MA, Cançado JED, Pereira LAA, Braga ALF, Saldiva PHN. Queima de biomassa e efeitos sobre a saúde. J Bras Pneumol [Internet]. 2004 Apr [cited 2015 Nov 4]; 30(2):158-175. Available from: http://www.scielo.br/scielo.php?script=sci_arttext\&pid $=$ S1806-37132004000200015\&lng $=$ en\&n$\mathrm{rm}=\mathrm{iso} \& \mathrm{t} \operatorname{lng}=\mathrm{pt}$

27. Ribeiro H. Queimadas de cana-de-açúcar no Brasil: efeitos à saúde respiratória. Rev Saude Publica [Internet]. 2008 Apr [cited 2015 Nov 4]; 42(2):370-376. Available from: http://www.scielo.br/scielo.php?script=sci_ arttext\&pid=S0034-89102008000200026\&lng=en\&n$\mathrm{rm}=$ iso\&tlng=pt
28. Lopes FS. Análise de agravos à saúde e possíveis associações aos produtos da queima de cana-de-açúcar [tese]. São Paulo: Universidade de São Paulo; 2010.

29. Devalia J. Air pollutants and respiratory hypersensitivity. Toxicol Lett 1996; 86(2-3):169-176.

30. Instituto Brasileiro de Geografia e Estatística (IBGE). Cidades: indicadores e dados populacionais. Rio de Janeiro: IBGE; 2010.

31. Bryant-Stephens T. Asthma disparities in urban environments. J Allergy Clin Immunol 2009; 123(6):11991206; quiz 1207-1208.

32. Gold DR, Wright R. Population disparities in asthma. Annu Rev Public Health 2005; 26:89-113.

33. Brazil. Ministery of Health. Departamento de Atençao Básica [Internet]. 2014 [cited 2015 Nov 22]. Available from: http://dab.saude.gov.br/portaldab/

34. Antunes FP, Costa M da CN, Paim JS, Vieira-da-Silva LM, Cruz ÁA, Natividade M, Barreto ML. Desigualdades sociais na distribuição espacial das hospitalizações por doenças respiratórias. Cad Saude Publica 2013; 29(7):1346-1356.

35. Brazil. Ministery of Health. Cadastro de Estabelecimentos de Saúde [Internet]. 2014 [cited 2014 Nov 12]. Available from: http://cnes.datasus.gov.br/

36. Brazil. Ministery of Health. Portaria $n^{\circ} 221$, Ministério da Saúde [Internet]. Brasília; 2008 [cited 2015 Sep 6]. Available from: http://bvsms.saude.gov.br/bvs/saudelegis/sas/2008/prt0221_17_04_2008.htm

Artigo apresentado em 04/03/2016

Aprovado em 01/09/2016

Versão final apresentada em 03/09/2016 